\title{
vermpano
}

\section{Reading and technology The bigger picture}

read with interest Justine Alsop's article,

"Losing our minds," ${ }^{1}$ calling for academic librarians to examine the effects of technology on reading and reflection. Alsop suggests, as others have done elsewhere, ${ }^{2}$ that our increasing engagement with computers is diminishing our ability to read and think deeply, broadly, and reflectively. As a former literature librarian and brand-new e-learning librarian whose responsibilities have migrated toward the digital, I find myself curious about these questions, and wary of easy answers.

It's hard to argue against a sea change in reading habits, given both anecdotal evidence from college campuses across the country and the findings of "Reading at Risk," the National Education Association's 2004 survey of literary reading in America. Less than half of the adult American population now regularly engages in reflective and sustained reading, and fewer young readers are taking up the habit. ${ }^{3}$ But is this change due to the intrusion of e-mail, full-text articles, and Google into our lives? Are we busier, more distracted, and less able to find time to reflect because we use computers?

\section{The changing student landscape}

I don't know of a definitive answer to this question. I suspect, however, that conversations about reading, reflection, and technology should ask more complex questions than this, and should take into account not only changes in how we teach, but in how our students live.

For example, if we want to explore changes in the quality of higher educa- tion - and in our students' ability to read in a leisurely, reflective way-we might begin by discussing the rising cost of tuition. Beginning in the 1980s, the price of higher education began to rise faster than the Consumer Price Index, with a sharp spike around the year 2000. ${ }^{4}$ By the 2003-04 academic year, the average total cost of a year's worth of public education (including room, board, in-state tuition, and fees) was estimated to be $\$ 15,200 .^{5}$ Essentially, today's students are under unprecedented pressure to pay their bills. Many students work part-time or even full-time jobs to make ends meet, and many have no choice but to take out loans. Facing tight post-grad job markets and looming repayment schedules, students may view a university degree not so much as an opportunity to pore over the classics of English literature, but as a four-year scramble to position themselves as well as possible for the future.

At the same time, changes in the American job market, in personal aspirations, and in the ethnic and economic makeup of the country have radically changed student demographics. The "average" undergraduate is no longer average. Many students are parents or family caretakers, with tight schedules and competing priorities. Many are returning to higher education after years away, working or building a family. Many are coming from backgrounds served poorly by academe-students who are the

Karen Munro is e-learning librarian at the University of California-Berkeley, e-mail: kmunro@library.berkeley.edu

๑ 2006 Karen Munro 
first in their family to attend a university, or members of ethnic or cultural minorities. As pleasant as it is to consider a university degree an opportunity for prolonged and leisurely reflection, most students are in no position to spend their time this way. And it's worth remembering that only a very small number of highly privileged individuals has ever been in that position.

It's certainly possible that technology, and computers in particular, play a role in fragmenting our attention and hamstringing our ability to read deeply. But before we point another finger at Google, let's think about the increasing pressures on our students, and about the new demands they're making on higher education systems. As librarians, perhaps we can lead the way in using technology wisely, to help mitigate the stress we all feel in our studies, jobs, and lives.

\section{Using technology responsibly and well}

Librarians may not be able to do much about the gradual erosion of the American middle class, or the inflation of university credentials, but we should be able to use our research and information skills to filter the most useful new tools from the deluge of dross. After all, technology is simply "[a] particular practical or industrial art." ${ }^{6}$ It may be helpful to remember that the printed book is a technology-and a very good one. Computers may be a more complex technology, with their own set of idiosyncrasies, but they offer an enormous range of potential benefits.

Computers allow us to communicate cheaply and instantly, to open our classes to an ever-growing population of students, to translate lectures into multiple languages, to save our students' money. Used properly, they should at the very least free up student, staff, and faculty time for more important things, like reading literature and debating politics. But, in my opinion, the biggest challenge we face is in learning how to use technology responsibly and well. To do so, we must first clearly articulate the good that we want to preserve and strengthen.
Digital technologies have evolved so quickly that most teachers, librarians, and even students feel perpetually off balance, wondering what's going to emerge next and often less than thrilled by what we've seen so far. It's important to remember how short the timeline has been, and to take the long view for the future. The world is changing around our students, not just technologically but politically and economically. It's our responsibility not to throw up our hands and mourn the loss of a golden era of education, but to use the tools and skills we have to brighten the path that lies ahead.

\section{Notes}

1. Justine Alsop, "Losing our minds," CERL News 66, no. 11 (2005): 790-91.

2. Notably, Sven Birkerts's The Gutenberg Elegies (Faber and Faber, 1994) and Neil Postman's Technopoly (Knopf, 1992])

3. National Endowment for the Arts, Reading at Risk: A Survey of Literary Reading in America (2004), ix; xi.

4. National Center for Education Statistics, "Paying for College: Changes Between 1990 and 2000 for Full-Time Dependent Undergraduates" (2004), 2. http://nces.ed.gov /pubs2004/2004075.pdf.

5. National Center for Education Statistics, "National Postsecondary Student Aid Study" (2004), http://nces.ed.gov/das/library/tables_ listings/show_nedrc.asp?rt=p\&tableID=1405.

6. OED Online, s.v. "Technology" (accessed January 3,2006 ). $\approx$

("Brazilian studies" continued from page 311)

these developments. Online resources for Brazilian studies, therefore, are as abundant as they are expanding. This column offers a hint of the richness of information and techniques for access that are available. A Brazilian expression for "getting things done" is having jeito (JAY-too, that is, "know-how," practical "savoir-faire"). Herewith, therefore, has been a hand up for your jeito in doing Brazilian studies. $\boldsymbol{z}$ 